\title{
Analysis and Prevention of Enterprise Financial Risk under the New Tax Policy
}

\author{
Atayev Meylis \\ South China University of Technology, Guangzhou, China \\ Email: meylis200891@mail.ru
}

How to cite this paper: Meylis, A. (2019) Analysis and Prevention of Enterprise Financial Risk under the New Tax Policy. Open Journal of Business and Management, 7, 1943-1952. https://doi.org/10.4236/ojbm.2019.74133

Received: September 27, 2019

Accepted: October 14, 2019

Published: October 17, 2019

Copyright $\odot 2019$ by author(s) and Scientific Research Publishing Inc. This work is licensed under the Creative Commons Attribution International License (CC BY 4.0).

http://creativecommons.org/licenses/by/4.0/

\begin{abstract}
In order to better protect the development of private enterprises in China, China launched a larger tax reduction policy in 2019. Under the new tax policy, enterprises can effectively adjust itself and it has important significance for enterprises to protect and control their own financial risk. This paper takes Shenzhen A Enterprise as an example, puts forward countermeasures to ensure that the enterprise can better develop and grow through the study of the new tax policy and the financial management of the enterprise.
\end{abstract}

\section{Keywords}

New Tax, Policy, Enterprise Financial Risk, Prevention

\section{Introduction}

Enterprise financial management refers to the possibility of deviating from the expected target in the process of financial operation, which belongs to the micro-economic risk [1]. Enterprise financial management includes the risk of financial income and the risk of financial status. Financial income mainly refers to the ability of the enterprise to indebted and gain benefits from operation. The target deviation refers to the increase or decrease of financial income, and the variation or improvement of financial income. The uncertainties in financial activities have a great influence on the financial relations and expected profits and losses of enterprises. The broad sense of enterprise financial management refers to that in the process of operation, the economic consequences are uncertain, there may be profit or loss; the narrow sense of enterprise financial management mainly refers to loss.

Since 2019, China has implemented a new tax policy and the new round of initiatives has included four main aspects. The first is to implement preferential tax relief for small and micro enterprises. This policy has been issued to the pub- 
lic. The minimum threshold for small-scale VAT taxpayers has been raised, and the monthly sales volume has been adjusted from 30,000 Yuan to 100,000 Yuan, that is, if enterprise's monthly sales is less than 100,000 Yuan, it no longer has the obligation to pay value-added tax. The new policy relaxes small Low-profit enterprises standard restrictions and increases its preferential margins. The relaxed conditions are as follows: the total assets of enterprises are less than 50 million Yuan, the number of employees is less than 300, and the taxable income is less than 3 million Yuan [2]. Therefore, it is of great significance to study the financial management of enterprises under the new form of tax policy. This paper takes Shenzhen A Enterprise as an example, through analyzing its financial management status in recent years, and combining with the new tax policy, puts forward the countermeasures to promote the development of enterprise financial management.

\section{Company Profile and Organizational Structure}

\subsection{Company Profile}

In 2001, Company A was established in 1202, Block B, Shandong Building, Nanhai Avenue, Nanshan District, Shenzhen City, Guangdong Province. It is a construction enterprise with professional qualification for foundation and basic works approved by Guangdong Provincial Construction Department. At present, the company's main business is: 1) Slope support and foundation pit support engineering; 2) Cast-in-place bored pile, Revolving Digging Cast-in-Place Bored Pile, grooving machine, static pressure pipe pile, hammering pipe pile, seismic sand-washing pile, and other foundation engineering construction; 3) composite foundation treatment engineering, including vacuum preloading, surcharge preloading, dynamic consolidation by drainage and other relevant combined method, cement mixing pile, CFG pile, high-pressure jet grouting pile, sleeve valve pipe grouting, etc. 4) Construction of steel trestle, steel platform, temporary wharf and sightseeing Wharf. 5) Mechanical equipment leasing. 6) Basic testing.

\subsection{Financial Status of Shenzhen A Company}

\subsubsection{Financing Activities}

According to the relevant financial statements of A company, in 2016, the company had 103.665.16 million fixed assets. In 2017 fixed assets increased to 112.233 million, and in 2018, fixed assets reached to 11.89 .259 million, so it can be concluded that the company's financing activities are not bad and relatively stable.

\subsubsection{Operational Activities}

From the financial statements of A company, it can be seen that in recent years, the company has maintained the turnover days of accounts receivable in about 25 days and company A's accounts receivable turnover rate is relatively fast, may be the credit policy of A company is more stringent. Therefore, in the long run, 
it may affect the expansion of enterprise scale, thus affecting the long-term profitability of the enterprise.

\subsubsection{Revenue Distribution Activities}

As can be seen from the A's financial statements: the profit available for distribution in 2016 was RMB14,988,735.3, the profit available for distribution in 2017 was RMB20,567,450.11, and the profit available for distribution in 2018 was as high as RMB25,008,313.46, which shows that Company A's profit increased annually.

\subsection{Analysis of the Main Financial Ratio of Shenzhen A Company}

\subsubsection{Analysis of the Company's Solvency Indicators for 2018}

As can be seen from Table 1, the liquidity ratio of A in 2018 is declining, indicating that the solvency of enterprises is declining. In the days of inventory turnover, the company maintained a low level, which can show that the company has a higher sales and profitability, and also has a certain strength in the ability to repay short-term debt. From the aspect of asset-liability ratio, the company has increased from $8.5 \%$ at the beginning of the year to $11.43 \%$. It can be seen that the enterprise's debt ratio has increased, which has a certain relationship with the reform of the enterprise in that year.

\subsubsection{Analysis of Company Profitability Indicators in 2018}

As can be seen from Table 2, the company's asset profit margin is basically maintained at $13 \%$. As an engineering company, its overall profit margin is basically at the average level of the industry. In terms of the net interest rate of shareholders' equity, the company is $14 \%$, which is basically consistent with the profit margin of assets of the whole enterprise. In 2018, the company's sales interest rate dropped from $11 \%$ at the beginning of the year to $8 \%$, and its net sales interest rate declined to a certain extent, indicating that the business operation process in 2018 was affected by the overall economic situation.

\subsubsection{Analysis of the Operating Capability Indicators of the Company in 2018}

As shown in Table 3, receivable turnover rate equals to net sales income on

Table 1. Analysis of corporate reparability indicators.

\begin{tabular}{ccccc}
\hline \multicolumn{2}{c}{ Current Ratio } & \multicolumn{2}{c}{ Inventory Turnover Days } & \multicolumn{2}{c}{ Asset-liability Ratio } \\
\hline Early Year & Year End & \multirow{2}{*}{0.08} & Early Year & Year End \\
7.65 & 6.19 & & $8.5 \%$ & $11.43 \%$ \\
\hline
\end{tabular}

Table 2. Analysis of company profitability indicators.

\begin{tabular}{cccc}
\hline Asset Profit Margin & Return on Shareholder's Equity & \multicolumn{2}{c}{ Sales Net Interest Rate } \\
\hline $13 \%$ & $14 \%$ & Early Year & Early Year \\
& & $11 \%$ & $8 \%$ \\
\hline
\end{tabular}


Table 3. Company A operating capability indicators in 2018.

\begin{tabular}{ccc}
\hline $\begin{array}{c}\text { Accounts Receivable } \\
\text { Turnover Rate }\end{array}$ & $\begin{array}{c}\text { Current Asset } \\
\text { Turnover Rate }\end{array}$ & $\begin{array}{c}\text { Total Asset } \\
\text { Turnover Rate }\end{array}$ \\
\hline 3.56 & 2.25 & 1.53 \\
\hline
\end{tabular}

credit/average balance of accounts receivable, the higher the turnover rate of accounts receivable, the shorter the turnover days of accounts receivable, indicating that the faster the receivable is returned, the stronger the liquidity of accounts receivable, and the smaller the possibility of bad debts occurring in accounts receivable, but if the turnover rate of accounts receivable of an enterprise is too high, it may be due to the fact that the credit policy of the enterprise is too harsh, which may limit the size of the enterprise's sales and affect the long-term profitability of the enterprise [3].

The turnover rate of current asset equals to main business income/ the average balance of current assets. The higher the turnover rate of current assets, the shorter the turnover days of current assets, which means that faster turnover of current assets has better utilization. The analysis of the overall turnover of current assets should be combined with the turnover of specific current assets such as inventory and accounts receivable and other specific liquid assets turnover situation [4].

Total assets turnover rate equals to main business income/average total assets. It has been known that the higher the total assets turnover rate, the shorter the total assets turnover days. which means that the faster the turnover of all assets of the enterprise, the more income the same assets will be earned, so the higher the management level of the assets [5]. The turnover rate of A company's total assets is only 1.53, so the management level of enterprises is not high.

\subsection{Possible Financial Management of Shenzhen Company A}

\subsubsection{Analysis of Financial Management of Shenzhen A Company from Balance Sheet}

As shown in Table 4, Asset-liability ratio is the ratio of total liabilities to total assets. It is an important index to measure the long-term repayment ability of $\mathrm{A}$ company. From the standpoint of creditors, the lower the asset-liability ratio is, the better results show. While from the debtor's point of view, if the interest paid by the capital involved is lower than the profit brought by its capital, the higher the asset-liability ratio is, the better. General experience tells us that the best asset-liability ratio is close to $60 \%$. From the calculation results can be seen that Company A for four consecutive years of asset-liability ratio is well below the $60 \%$ indicator, so it is learned that A company's long-term ability to repay foreign debt will not occur financial management.

\subsubsection{Analysis of Financial Management of Shenzhen A Company from Profit Statement}

As can be seen from the Table 5, Company A's profits in recent years are decreasing year by year, which indicates that the profitability of the company is declining. 
Table 4. Company A's asset-liability ratio statistics.

\begin{tabular}{ccccc}
\hline Year & 2010 & 2016 & 2017 & 2018 \\
\hline Asset-Liability Ratio & $10.22 \%$ & $10.86 \%$ & $8.5 \%$ & $11.43 \%$ \\
\hline
\end{tabular}

Table 5. A company asset profit rate statistics.

\begin{tabular}{cccc}
\hline Year & 2016 & 2017 & 2018 \\
\hline Company Asset Profit Rate & $19 \%$ & $18.98 \%$ & $13 \%$ \\
\hline
\end{tabular}

Therefore, A company should take certain measures to improve the profitability of the company. So that the company's competitiveness in the same industry can be improved.

\subsubsection{Analysis of Financial Management of Shenzhen A Company from Cash Flow Statement}

It can be seen from the Table 6 that the repayment of current liabilities of enterprises is still reliable, so A will not have financial management in cash flow.

\section{Analysis of Financial Management of Shenzhen A Company}

\subsection{Project Cost}

Shenzhen A Company should actively carry out technical innovation and equipment management in the process of bidding project construction. According to the design scheme and technical data required by customers, combined with the construction contract and the conditions of the construction site, to work out the most reasonable and effective construction program, as far as possible to shorten the duration, improve the utilization of equipment, adopt new technology to improve the construction quality in order to reduce the cost of the project. Equipment support department management personnel is to strengthen the management of machinery and equipment, construction materials and other engineering materials. In the process of purchasing, prices with quality should be compared, selecting products with reasonable quality and price, strictly managing in the process of using, avoiding material waste and equipment damage, saving engineering costs. The personnel cost of enterprises should also be strictly controlled, and the responsibility system should be implemented. Every post has a special person in charge. If something goes wrong, someone should assume responsibility, paying salaries according to the post, and determine the management cost of the performance appraisal method of reward and punishment for the construction personnel by personal performance. Unreasonable expenses and waste are deducted from the wages of the persons responsible. After the project cost is compressed, the profit of the enterprise shall increase correspondingly, and the financial management of the enterprise shall be reduced from the aspect of capital.

\subsection{Contract Management}

Shenzhen A Company must carefully study the terms of the contract when signing 
Table 6. A company cash current debt ratio.

\begin{tabular}{cccc}
\hline Year & 2016 & 2017 & 2018 \\
\hline Cash Current Debt Ratio & 1.56 & 1.67 & 1.08 \\
\hline
\end{tabular}

a contract with its customers and asking professional lawyers to give effective suggestions to avoid and eliminate possible economic disputes in the follow-up. When the contract involves the time and norms of project acceptance, the calculation of project repayment and other breaches of contract clauses, it is necessary to clearly divide the economic responsibilities of both parties, not ambiguous, and must implement the responsibilities to individuals. The clause of alteration claim should be considered comprehensively to prevent the loss from being compensated when the alteration occurs in construction which is different from the design scheme. For unreasonable or unenforceable clauses, objections should be raised between the signing of the contract, so that customers can change the content of the clauses and reduce the financial management of their units.

\subsection{Insufficient Internal Accounting Control System}

Based on abiding by the relevant economic laws and regulations of the state, the accounting control system within Company A has many deficiencies in the financial management of the project construction process, which is formulated in accordance with its own business model and project management mode. The implementation of accounting basic work will enable accounting work to play an effective role in improving the company's business efficiency.

\subsection{Changes in the Domestic Macro-Environment}

The State to stimulate the development of construction industry has a certain regulatory effect on the economy. When the economy is overheated, the state will reduce the investment in the construction industry and restrict the development of the industry. At this time, the profit of A company will decrease dramatically. Uncertainty factors such as policies and regulations issued by the state will also affect the financial situation of A company. When the economy is depressed, it will also increase the financial management of A company.

\section{Analysis of Financial Management Countermeasure of Shenzhen A Company}

\subsection{Actively Establish a Perfect Risk Prevention Mechanism}

Perfect risk prevention mechanism can make the management mechanism of A company run normally and effectively and can improve the operation efficiency of A company and the scientific nature of major decisions. Shenzhen A company has many problems like, a very unclear structure on property rights, ambiguous division of authority and responsibility between the board and the manager, bossy instructions of the supreme leader, inefficient operation of the whole 
company management, staff procrastination and strategic decision-making mistakes and so on.

First of all, to improve the company's management structure, let the leaders of departments within the company check and balance each other's rights, supervise each other, establish a clear reward and punishment system and the right to dismiss, so that employees have a sense of crisis, do well and reward, do poorly may be to go to this job, stimulate them to work hard. Secondly, he implementation of the corporate legal person system, once the system is established, it needs strict implementation and supervision. The separation of operation power and management power should be achieved so that the incentive mechanism and restriction mechanism within the company can operate normally. Finally, to improve the management system of project funds, because the construction operation of the project requires a large amount of capital operation, so the financial management of the project is the management focus of Company A.

In addition to improving the financial management prevention mechanism, financial management alert mechanism should also be strengthened, which is of great significance to the prevention and timely response of enterprise financial management and can fundamentally improve the ability of an enterprise to resist financial management. Market economy is free, there are many uncertain factors in the process of production and operation of enterprises, and there are great risks in the financial situation of enterprises. Therefore, it is necessary to establish an early warning mechanism for financial management, which can not only discover the problems in the middle of financial management as early as possible, but also deal with the crisis in time so as to make decisions, giving decision makers plenty of time to develop effective business strategies, control and manage the expansion of corporate financial crises, and further reserve enough safety time for eliminating the crisis.

\subsection{Establishing an Effective Management System and Structure within an Enterprise}

Establishing an effective internal management system is an important measure to prevent and control the emergence of financial management in enterprises $\mathrm{A}$. Effective management system can make the internal operation of the company scientific, standardized and institutionalized, so that the various processes in the process of production and operation can be carried out according to plan, can enhance the ability of enterprises to resolve financial management. Strengthen the research on the internal management system and emergency measures of Enterprise And create a set of scientific prevention and control institutions suitable for the company. Secondly, it is necessary to establish an internal review system, which can help enterprises to carry out financial management and prevention and control supervision, so that the economic activities of enterprises can be fully audited and supervised, to find out the possible problems in the accounting system, to establish an efficient and convenient accounting system model, and to enhance the response capacity of the financial departments of en- 
terprises. Speed up the time of financial decision-making, reduce financial management, clear the responsibilities of each department in their own use, distribution, management responsibilities, do not overstep the authority to operate.

\subsection{Enhancing the Financial Management Awareness of Policymakers and Financial Personnel}

As the steerer of the enterprise, whether the decision-maker can avoid the storm of financial management is closely related to the wisdom of the decision-maker and the correct understanding of financial management. A enterprise all production and operation activities and financial management of all work need its decision-makers and accounting personnel to fully cooperate. In order to achieve the goal of preventing and controlling the financial management of enterprise A, first of all, the decision makers and the managers of rough and fast departments should strengthen the precautionary consciousness of financial management, and then the relevant personnel of various departments of enterprise A should be strengthened. Popularize certain financial knowledge, especially the training of financial management consciousness in the working, so that they can understand the possible links and forms of financial management, how to prevent and resolve financial management, financial management hazards and other knowledge, and strengthen the ability of enterprise managers and normal employees to control risks.

\subsection{Continuous Improvement of the Quality of Financial Personnel}

Modern enterprises raise the awareness of financial management prevention and control of managers and ordinary employees, at the same time, higher requirements for the comprehensive quality of financial personnel was put forward. Financial personnel should not only be familiar with the knowledge of finance, law, financial economy and management, but also charge up the knowledge of financial prevention. With the continuous development and growth of enterprises, new opportunities and challenges have been put forward to the managers and financial personnel of Company A. Firstly, their comprehensive qualities are required. They should integrate information according to market conditions, product research and development and internal financial conditions, constantly improve their lack of knowledge in some respects and to improve their management and ability to deal with financial management crises.

\subsection{Establishing a Reasonable Capital Structure}

Capital structure refers to the proportion relationship between equity funds and liabilities funds in the company's own source. Shenzhen A company's internal liabilities account for a high proportion of all funds, which makes the cost of corporate liabilities high, and the heavy burden makes their solvency too low, so their ability to deal with financial management is naturally poor. Therefore, it is urgent to establish a reasonable capital structure. 


\subsection{Strengthen the Enterprise's Response Ability}

The audit department of A company should give full play to its auditing and supervising function, make a comprehensive financial management evaluation of the company's project investment, fixed assets investment and external investment, and determine which are systemic investment risks and which are non-systemic investment risks. Once the specific situation of these risks is recognized and then can make the right strategic decisions and invest in projects where financial management is manageable and can generate strong profits for the business.

\subsection{Strengthen the Daily Funds Management}

Shenzhen A company should clearly understand the current profitability and the total amount of idle funds, annual investment in capital projects, and so on, rationally arrange the use of funds, reduce the occupation of worthless funds, and accelerate the turnover of company funds. Reduce the proportion of the company's liabilities in the total amount of funds, improve debt solvency, and constantly adjust the capital structure, so that limited capital can create unlimited economic benefits.

\subsection{Collaborate with other Companies to Decentralize Financial Management}

Risks and benefits are proportional to a certain extent. Cooperation with other companies can enhance the financing capacity of Shenzhen A Company. Tourists and other companies can share the financial management that may arise from investment risks. However, when Shenzhen A Company shares financial management with other companies, it will lose the huge profits obtained by solely undertaking the project. Shenzhen A company should find its own choice between risk and benefit according to its own economic strength, capital capacity, technology research and development ability, and combining with the characteristics of the project itself.

\subsection{Promoting Risk Control of Engineering Projects}

Under the condition of market economy, Shenzhen A Company is facing multiple risks. To develop rapidly and sustainably, enterprises need to have strong ability to resist financial management and control risks. Project risk refers to the possibility of negative consequences in dazzling management process. Risk control is the analysis and treatment of possible uncertainties, including risk identification, analysis and evaluation, and countermeasure research and implementation, according to the environment and expected management objectives of engineering risks.

\section{Conclusion}

With the implementation of China's new tax policy, enterprises have new prefe- 
rential policies in terms of value added tax and social security fees, which is very beneficial for the development of enterprises. On the basis of the development in 2018, the A company should combine with the new tax policy, strengthen the financial management of enterprises, and put forward better management plans according to the development of enterprises, so as to lay a solid foundation for promoting the long-term development of enterprises.

Due to the rapid development of the market, this paper mainly based on the accounting situation of company A in 2018, which is one-sided. In the future development of the company, the financial situation will change, and the relevant policies will also change. Therefore, in terms of financial management strategy, it should be analyzed according to the development at that time in order to achieve good results.

\section{Conflicts of Interest}

The author declares no conflicts of interest regarding the publication of this paper.

\section{References}

[1] Tian, L. (2019) Use Electronic Information Technology to Innovate Financial Management and Services. Information and Computers (Theory), 1, 71-72.

[2] Shen, J. (2019) The Establishment and Perfection of Financial Management and Internal Control System in the New Era. China's Collective Economy, 4, 130-131.

[3] Zhao, J.W. (2019) Research on Financial Risk Management of Construction Enterprises. China's Collective Economy, 4, 150-151.

[4] Ye, F. (2019) Effect of Replacing Business Tax with Value-Added Tax on Financial Management of Telecommunication Enterprises and Countermeasures. Economic and Trade Practice, 2, 85.

[5] Ding, C. (2019) The Application Research of Financial Analysis in Enterprise Financial Management. Economic and Trade Practice, 2, 100-102. 